\title{
EVALUATION OF LOW BACK PAIN IN PATIENTS WHO UNDERWENT BARIATRIC SURGERY
}

\author{
AVALIAÇÃO DA DOR LOMBAR EM PACIENTES SUBMETIDOS À CIRURGIA BARIÁTRICA \\ EVALUACIÓN DEL DOLOR LUMBAR EN PACIENTES SOMETIDOS A CIRUGÍA BARIÁTRICA \\ Lara Guercio dos Santos, ${ }^{1}$ Guilherme Yukio Kajya Amuka, ${ }^{1}$ Lucas Claravolo Gaspar, ${ }^{1}$ Thiago Kolachinski Brandấ, ${ }^{1}$ Luciano Miller Reis Rodrigues, ${ }^{1}$ \\ Adriano Masayuki Yonezakl, ${ }^{1}$ André Evaristo Marcondes Cesar, ${ }^{1}$ Fernanda Amate Lopes ${ }^{1}$ \\ 1. Hospital Estadual Mário Covas, Santo André, SP, Brazil.
}

\begin{abstract}
Objective: Low back pain is an extremely common condition that can affect up to $84 \%$ of people at some point in life. It affects patients of both sexes, mainly between 30 and 50 years of age, and has a great impact on the quality of life, in addition to placing a significant demand on health services. Obesity is considered as an important risk factor for the development of low back pain since the change in body fat distribution causes changes in the locomotor system and especially in the spine. Methods: The study makes a comparative, retrospective analysis of patients who underwent bariatric surgery through questionnaires to assess the improvement in their quality of life and low back pain. The data were submitted to a statistical analysis and the results compared to the literature data. Results: As a result, there was a statistically significant improvement in quality of life in relation to weight loss; the greater the weight reduction, the better the quality of life and the younger the patient, the better their quality of life. Conclusions: When asked about low back pain, $70.7 \%$ of patients classified it as moderate to severe. Level of evidence III; Comparative retrospective.
\end{abstract}

Keywords: Low Back Pain; Bariatric Surgery; Quality of Life; Spine.

\section{RESUMO}

Objetivo: A dor lombar é uma condição extremamente comum que pode acometer até $84 \%$ das pessoas em algum momento da vida. Atinge pacientes de ambos os sexos, principalmente entre 30 a 50 anos de idade e tem grande impacto na qualidade de vida dos pacientes, além da importante demanda que ocasiona aos serviços de saúde. A obesidade é considerada um fator de risco importante para o desenvolvimento de dor lombar, uma vez que a mudança da distribuição da gordura corporal causa alterações no aparelho locomotor e, em especial, na coluna vertebral. Métodos: 0 estudo faz uma análise comparativa retrospectiva dos pacientes submetidos à cirurgia bariátrica por meio de questionários, com o objetivo de avaliar a melhora da qualidade de vida e a dor lombar desses pacientes. Os dados foram submetidos a uma análise estatística e os resultados comparados aos dados presentes na literatura. Resultados: Como resultado, houve relevância estatística na melhora da qualidade de vida com relação à perda de peso; quanto maior a redução de peso melhor a qualidade de vida, e quanto menor a idade, melhor a qualidade de vida do paciente. Conclusões: Quando questionados sobre a dor lombar, 70,7\% dos pacientes classificaram a dor de moderada a intensa. Nível de evidência III; Retrospectiva comparativa.

Descritores: Lombalgia; Cirurgia Bariátrica; Qualidade de Vida; Coluna Vertebral.

\section{RESUMEN}

Objetivo: El dolor lumbar es una condición extremadamente común que puede afectar hasta 84\% de las personas en algún momento de la vida. Afecta a pacientes de ambos sexos, principalmente entre 30 y 50 años de edad y tiene un gran impacto en la calidad de vida de los pacientes, además de la importante demanda que ocasiona a los servicios de salud. La obesidad es considerada un factor de riesgo importante para el desarrollo del dolor lumbar, ya que el cambio de la distribución de la grasa corporal causa alteraciones en el sistema locomotor y especialmente en la columna vertebral. Métodos: El estudio realiza un análisis comparativo retrospectivo de los pacientes sometidos a cirugía bariátrica mediante cuestionarios, para evaluar la mejora de la calidad de vida y el dolor lumbar de estos pacientes. Los datos fueron sometidos a un análisis estadístico y los resultados se compararon a los datos presentes en la literatura. Resultados: Como resultado, hubo relevancia estadística en la mejora de la calidad de vida con relación a la pérdida de peso; cuanto mayor es la reducción de peso mejor es la calidad de vida, y cuanto menor es la edad, mejor es la calidad de vida del paciente. Conclusiones: Cuando cuestionados sobre el dolor lumbar, 70,7\% de los pacientes calificó el dolor de moderado a intenso. Nivel de evidencia III; Retrospectivo comparativo.

Descriptores: Dolor de la Región Lumbar; Cirugía Bariátrica; Calidad de Vida; Columna Vertebral.

\section{INTRODUCTION}

Low back pain is an extremely common condition that can affect up to $84 \%$ of people at some point in life. It affects patients of both sexes, mainly between 30 and 50 years of age, and has a great impact on quality of life in addition to the important demand it places on healthcare services. ${ }^{1}$
According to the National Household Sample Survey (PNAD) of the Brazilian Institute of Geography and Statistics (IBGE), spinal pain (cervical, thoracic, lumbar, and pelvic) is the second most prevalent health condition in Brazil (13.5\%) among chronic pathologies identified by a physician or health professional, surpassed only by cases of hypertension. ${ }^{2}$ 
Low back pain can be caused by muscle tension, rheumatological disorders, degenerative diseases, psychological disorders, and various pathologies including obesity, tobacco use, physical inactivity, and the increase in life expectancy are risk factors for low back pain. ${ }^{8,13}$

In the treatment of low back pain, studies show the importance of physical activity and muscle strengthening to reduce low back pain crises. The literature describes how physical activity helps both in the treatment of low back pain and in the prevention of new pain crises and shows a relationship between physical inactivity and changes in the spine that cause physical disability resulting from low back pain. ${ }^{18-20}$

Studies that correlate obesity and low back pain report conflicting results. Most positively correlated obesity to an increase in low back pain, but it is possible to find studies in the literature that argue that there is no direct correlation between low back pain and obesity. ${ }^{7,11}$

Significant changes in the profile of the Brazilian population have occurred in recent years, with the increase in the number of elderly people and in sedentary habits. Consequently, changes are being observed in body composition, with an increase in overweight and obesity rates currently reaching $58.4 \%$ in women and $52.5 \%$ in men. . $^{8,12}$

Obesity is considered a chronic non-communicable disease and a worldwide epidemic, causing around 2.5 million deaths per year. It is defined as the abnormal or excessive accumulation of body fat in the form of adipose tissue, which can cause health risks. ${ }^{5,6,10}$

The World Health Organization (WHO, 2000) classifies obesity according to the body mass index (BMI) calculation (weight/height ${ }^{2}$ ), with BMI from 30.0 to $34.9 \mathrm{~kg} / \mathrm{m}^{2}$ being class I obesity, with BMl from 35.0 to $39.9 \mathrm{~kg} / \mathrm{m}^{2}$ as class II obesity, and with BMl equal to $40.0 \mathrm{~kg} / \mathrm{m}^{2}$ as class III obesity. ${ }^{9}$

Obesity can lead to the development of several serious and debilitating diseases, including hypertension, diabetes mellitus, hyperlipidemia, respiratory disorders (hypoventilation, sleep apnea), degenerative osteoarthritis, venous stasis ulcers, cholelithiasis, gastroesophageal reflux, cerebral pseudotumor, menstrual disorders, infertility, psychosocial problems, and postural changes (the most commonly found are knee valgus, flat feet, and lumbar hyperlordosis). ${ }^{3,5,6,14}$

From a locomotor system perspective, obesity can cause numerous changes with an increased risk of pain and injuries involving all body segments, particularly the spine.,

The distribution of body fat, centrally or peripherally, interferes with the body alignment of the obese patient, promoting an overload and predisposing to the appearance of postural deviations associated with delayed activation of the spine stabilizing muscles and contributing to lumbar instability in the obese patient. 3,4

In the obese patient, excess weight makes it difficult to maintain spinal balance and stability during static posture, gait, and locomotion. Postural changes arise due to mechanical action performing under excess body weight and the increase in regional mechanical demands resulting in lumbar hyperlordosis, dorsal hyperkyphosis, and cervical hyperlordosis. , $^{3,4}$

Lumbar hyperlordosis is normally associated with weak abdominal muscles and the anterior inclination of the pelvis. The central accumulation of fat causes abdominal protrusion with consequent distension and muscle weakness, compromising the function of compression on the lumbar spine and generating an increase in lumbar lordosis. The increase in lordosis can lead to compensatory dorsal hyperkyphosis. ${ }^{3,4}$

Treating obesity involves pharmacological, dietary, and lifestyle (encouraging physical activity) interventions and cognitive-behavioral therapy. If there is refractoriness to conservative treatment after regular monitoring for at least two years, bariatric surgery may be indicated under certain clinical conditions. ${ }^{11,12}$

Interest in bariatric surgery grows significantly every year due to its good results in reducing the weight and improving the health of patients. In addition to weight loss, the goal of surgery is to control diabetes, hypertension, cardiovascular diseases, and osteoarticular problems and improve the quality of life of the patients. ${ }^{9}$

Bariatric surgery is indicated for patients with a body mass index
(BMI) of 40 or above or a BMl of 35 associated with comorbidities, such as sleep apnea, type II diabetes mellitus, arterial hypertension, dyslipidemia, locomotion difficulties, and other pathologies that are difficult to manage clinically. 5,9

As regards the type of surgery performed, none of the options is appropriate for all patients. However, the Roux-en-Y Gastric Bypass (RYGB) has been considered the most indicated treatment for class III obesity. ${ }^{6}$

The surgical procedure is a physical restriction that by itself does not provide all the desired benefits. It is necessary to change the patient's eating habits and behavior. To guarantee good results multidisciplinary monitoring with nurses, nutritionists, physicians, physical therapists, and psychologists is essential, ensuring adequate weight loss within health standards. ${ }^{9}$ Specifically, when the goal is to improve low back pain, the surgery should be accompanied by a program of physical activity for the treatment and prevention of low backpain, in which lumbar spine is stabilized and the lumbar and abdominal muscles are strengthened, increasing support capacity and decreasing mechanical overload in the lumbar region. ${ }^{18,19}$ Studies have shown that patients have significant reduction in muscle mass two years after surgery and that loss of muscle mass may occur even without significant changes in BMI. ${ }^{25}$

The objective of the study was to analyze low back pain in patients submitted to bariatric surgery and to evaluate whether weight loss is related to improved low back pain.

\section{METHODS}

Patients were invited to participate in the study and answer questionnaires about the preoperative and current postoperative situations. Age, sex, height, preoperative BMI, weight loss, BMI at the time of study, time since the surgery (in months), associated comorbidities, previous spinal procedures, physical activity, postoperative rehabilitation, and evaluation of the questionnaires will be assessed.

All the patients included in the study signed the Informed Consent Form after the study was approved by the Institutional Review Board of the Faculdade de Medicina do ABC (28441119.8.0000.0082).

To evaluate low back pain and the quality of life we administered three different questionnaires, the Visual Analog Scale (Figure 1) to score low back pain before and after weight loss on a scale from 0 to 10; the Short Form -36 (SF-36) (Appendix 1), a standard quality of life assessment questionnaire; and the Oswestry Disability Index (ODI) (Appendix 2) to measure lumbar symptoms.

The objective was to evaluate the differences between the preoperative and postoperative characteristics of the subjects, as well as the differences in the measurements of the results indicated by the Visual Analog Scale, SF-36, and ODI questionnaires, and finally the Oswestry 2.0 questionnaire.

Patients who underwent surgical lumbar spine procedures after having been submitted to bariatric surgery will be excluded.

\section{RESULTS}

According to the questionnaires, $90.80 \%$ of the patients who participated in the study were female, the mean age was 42.09 , the youngest being 26 years of age and the oldest being 65 years of age.

When we analyzed the associated comorbidities, 14 of the 65 patients made no reference to any associated comorbidity. Of those who referred to comorbidities, 34 cited arterial hypertension and 41 cited diabetes mellitus, or $52.3 \%$ with hypertension and $63.10 \%$ with diabetes as shown in Figure 2.

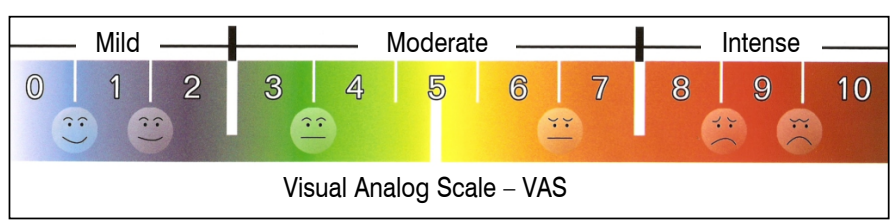

Figure 1. Visual analog scale. 
In relation to hypercholesterolemia, $86.2 \%$ of the patients mentioned this comorbidity, making it the most prevalent in the study. Only 9 of the participants referred to hypothyroidism, representing $13.8 \%$ of the total.

Figure 3 shows the responses to the visual analog scale for pain, in which the patients classified their pain on a scale from 0 to 10 , 0 to 2 being mild, 3 to 7 moderate, and 8 to 10 intense. Following bariatric surgery, thirty-two patients classified their low back pain as moderate and 14 patients classified it as intense, which together total $70.70 \%$ of the study patients reporting moderate to intense low back pain.

There was a large discrepancy in weight loss among the patients, ranging from $3 \mathrm{~kg}$ to $85 \mathrm{~kg}$ eliminated in the postoperative period. This is mainly due to the differences in the postoperative time periods when the measurements for each patient were taken and to the differences in their preoperative weights. As regards the weight of the patients prior to surgery, the mean was $118.2 \mathrm{~kg}$, with a minimum of $76 \mathrm{~kg}$ and a maximum of $170 \mathrm{~kg}$. In the postoperative period the mean weight loss was 29.73kg (Figure 4).

In the application of the Spearman Correlation Analysis between the weight loss of the patients and the questionnaires answered there was a statistically significant improvement in the relationship between weight loss and functional ability ( $p$ 0.001) and between weight loss and limitation by physical aspect ( $p$ 0049), indicating that the greater the weight loss the better the functional ability and the fewer the physical limitations (Table 1).

As regards the other aspects evaluated by the SF-36 (pain, vitality, general health, social aspect, mental health, and limitation by emotional aspect), there was no statistically significant relationship to weight loss (Table 1).

The relationship between weight loss and the Oswestry 2.0 questionnaire had a statistically significant correlation ( $p$ 0.010), showing that weight loss is associated with a better patient quality of life (Table 1).

When we applied the Spearman Correlation Analysis intending to verify the degree of the relationship between age and quality of life as measured by the Oswestry scale, we observed a significant result ( $p$ 0.004), indicating that quality of life is intimately related to age, i.e., the younger the patients, the better their quality of life (Table 2).

When questioned about physical activity, 50.80\% answered that they practice some form of physical exercise. As the activities

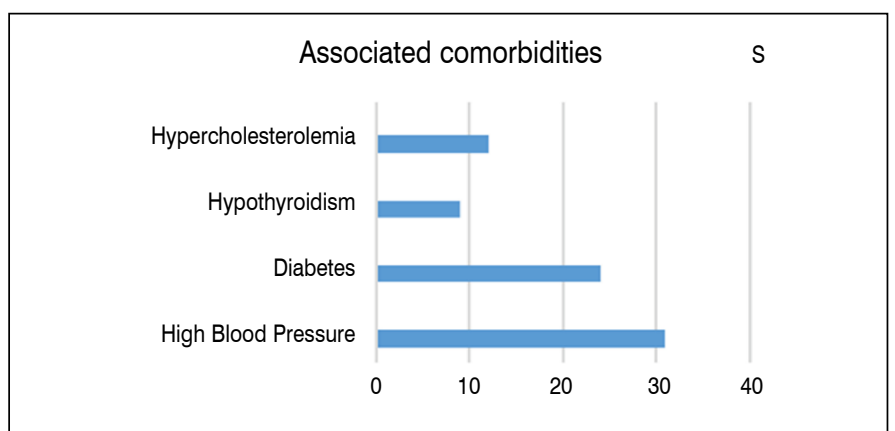

Figure 2. Patients with associated comorbidities raised in the application of the questionnaires.

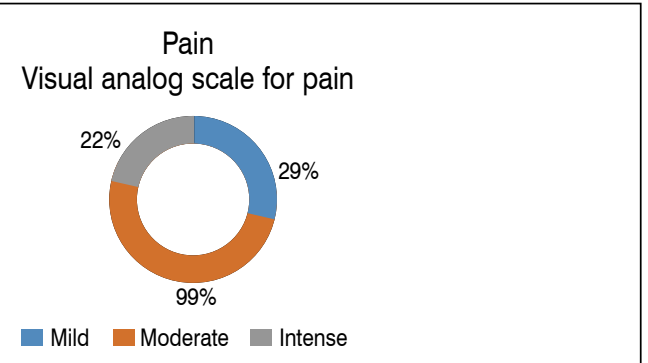

Figure 3. Percentage of the visual analog scale for pain. cited were extremely varied, no standard form of exercise aimed at maintaining muscle mass was observed among the patients. Twenty-four of the 32 patients who did not do any type of physical activity classified their low back pain as moderate to intense. Regarding the 33 patients who did refer to some type of physical activity, 20 of them classified their low back pain as moderate to intense. There was no statistical significance between the two groups evaluated

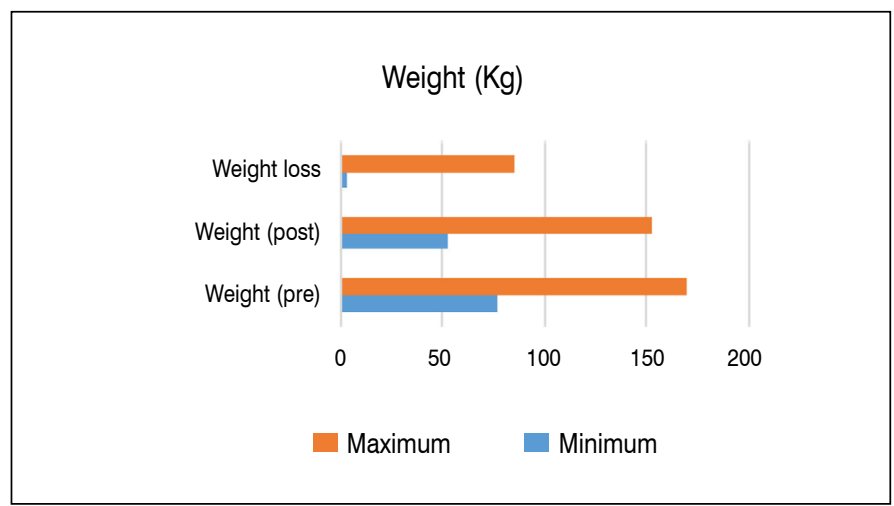

Figure 4. Representation of weight loss after undergoing bariatric surgery.

Table 1. Application of the Spearman Correlation Analysis to the relationship between weight loss and the other variables of interest.

\begin{tabular}{|c|c|c|}
\hline Variable & Statistic & Weight loss \\
\hline \multirow{3}{*}{ VAS } & Correlation Coefficient ( $r$ ) & -0.231 \\
\hline & Calculated Significance (p) & 0.064 \\
\hline & $\mathrm{n}$ & 65 \\
\hline \multirow{3}{*}{ [SF-36] Functional Ability } & Correlation Coefficient ( $r$ ) & +0.391 \\
\hline & Calculated Significance (p) & 0.001 \\
\hline & $\mathrm{n}$ & 65 \\
\hline \multirow{3}{*}{$\begin{array}{l}\text { [SF-36] Limitation by physical } \\
\text { aspect }\end{array}$} & Correlation Coefficient $(r)$ & +0.245 \\
\hline & Calculated Significance $(p)$ & 0.049 \\
\hline & $\mathrm{n}$ & 65 \\
\hline \multirow{3}{*}{ [SF-36] PAIN } & Correlation Coefficient $(r)$ & +0.194 \\
\hline & Calculated Significance (p) & 0.122 \\
\hline & $\mathrm{n}$ & 65 \\
\hline \multirow{3}{*}{ [SF-36] General Health } & Correlation Coefficient (r) & +0.042 \\
\hline & Calculated Significance (p) & 0.737 \\
\hline & $\mathrm{n}$ & 65 \\
\hline \multirow{3}{*}{ [SF-36] Vitality } & Correlation Coefficient $(r)$ & +0.194 \\
\hline & Calculated Significance $(p)$ & 0.122 \\
\hline & $\mathrm{n}$ & 65 \\
\hline \multirow{3}{*}{ [SF-36] Social Aspects } & Correlation Coefficient (r) & +0.160 \\
\hline & Calculated Significance $(p)$ & 0.203 \\
\hline & $\mathrm{n}$ & 65 \\
\hline \multirow{3}{*}{$\begin{array}{l}\text { [SF-36] Limitation by emotional } \\
\text { aspect }\end{array}$} & Correlation Coefficient $(r)$ & +0.187 \\
\hline & Calculated Significance $(p)$ & 0.135 \\
\hline & $\mathrm{n}$ & 65 \\
\hline \multirow{3}{*}{ [SF-36] Mental Health } & Correlation Coefficient (r) & -0.097 \\
\hline & Calculated Significance $(p)$ & 0.443 \\
\hline & $\mathrm{n}$ & 65 \\
\hline \multirow{3}{*}{ Oswestry 2.0} & Correlation Coefficient $(r)$ & -0.319 \\
\hline & Calculated Significance (p) & 0.010 \\
\hline & $\mathrm{n}$ & 65 \\
\hline
\end{tabular}

Table 2. Spearman Correlation Analysis between patient age and Oswestry 2.0

\begin{tabular}{c|c|c}
\hline Variable & Statistic & Age \\
\hline Oswestry 2.0 & Correlation Coefficient $(r)$ & +0.355 \\
\hline & Calculated Significance $(p)$ & 0.004 \\
\hline & $\mathrm{n}$ & 65 \\
\hline
\end{tabular}




\section{DISCUSSION}

In the present study, 65 patients who underwent bariatric surgery, most of whom had associated comorbidities, were evaluated. 9,15

In terms of the statistically relevant relationships, there was an improvement in the quality of life of the patients following bariatric surgery, mainly regarding limitations on daily activities by physical aspect. The study demonstrated that the greater the weight loss the better the quality of life and the less the limitation by physical aspect. The results found agree with other evidence in the literature that associate weight loss with improvement in the quality of patient life. .,16,17 $^{-17}$

The visual analog scale for pain showed that $70.7 \%$ of the patients referred to moderate to intense low back pain, however, when the tool is administered to the patient, the perception of pain is evaluated at that moment, not differentiating between acute and chronic pain. ${ }^{11}$

The difference observed in relation to the literature can be explained by several factors, such as, for example, the age of the participants. The improvement in quality of life was significant in younger patients. This may be associated with the non-differentiation between acute and chronic pain or could be due to postoperative rehabilitation through physical activity and the preservation of muscle mass.

In the literature there are reports of muscle mass loss with aging. The older the patient, the less muscle mass is expected, which can be a determining factor in the presence of low back pain, especially if associated with a sedentary lifestyle. ${ }^{21,22}$

In addition to the age factor, bariatric surgery causes a loss of muscle mass just as significant as the loss of fatty mass, which drastically reduces muscle strength and physical functions. ${ }^{23}$

Weakness of the musculature in the lumbar region is a determining factor for the complaint of low back pain and thus postoperative physical rehabilitation and muscle preservation are essential. ${ }^{2,5}$ Among the muscles that promote lumbar spine stability the deep abdominal muscles (transverse abdominis, internal oblique) together with the deep lumbar muscles (multifidus and quadratus lumborum) stand out. The transverse abdominis is especially important as its dysfunction results in lumbar instability. ${ }^{24}$

Studies have demonstrated the relationship between the practice of physical activity in the prevention and treatment of low back pain, the strengthening of the lumbar and abdominal musculature being especially important in lumbar spine stabilization. ${ }^{19,20}$

\section{CONCLUSION}

The obese patients who underwent bariatric surgery presented improvement in quality of life related to age and to the weight eliminated after the procedure. However, most of them classified their low back pain as moderate to intense even after weight loss, which is associated with the intense loss of muscle mass. The loss of lean mass results in a reduced muscle strength and low levels of muscle strength are associated with less ability to perform the activities of daily life. ${ }^{23}$

It is essential that there is a strategy for the maintenance and improvement of muscle strength in these patients through physical training programs. The possibility of a multidisciplinary protocol that helps patients in terms of physical activity and control of the percent of muscle mass lost in the postoperative period is suggested.

The author declare no potential conflict of interest related to this article.

CONTRIBUTION OF THE AUTHORS: Each author made significant individual contributions to this manuscript. LGS was the main author of the research article, FAL reviewed the ABNT notes and conducted the statistical data analysis, LCG and GYKS obtained and organized the data obtained from the quality of life questionnaires, LMRR, AEMC, TKB, and AMY analyzed the radiographic images, reviewed the manuscript, approved the final version of the manuscript, and contributed to the intellectual concept of the study.

\section{REFERENCES}

1. Zhang TT, Liu Z, Liu YL, Zhao JJ, Liu DW, Tian QB. Obesity as a Risk Factor for Low Back Pain- A Meta-Analysis, Clin Spine Surg. 2016;31(1):22-7.

2. Nascimento PRC, Pena Costa LO. Low back pain prevalence in Brazil: a systematic review. Cad Saúde Pública. 2015;31(6):1141-56.

3. Silva JF, Aragão MGL, Guerriei NA, Golçalves MM, Martins ABT, Madeira C. A relação entre alterações posturais e gordura localizada: revisão de literatura. Revista Diálogos Acadêmicos. 2014:3(2):117-23

4. Siqueira GR, Silva GAP. Postural alterations on the spinal column and lumbar instability in obese individual: a literature review. Fisioter Mov. 2011;24(3):557-66.

5. Kulcheski AL, Soler I Graells X, Benato ML, Baretta G. Evaluation of angular sagittal balance in obese patient. Coluna/Columna. 2013;12(3):224-7.

6. Melo IT, São-Pedro M. Musculoskeletal pain in lower limbs in obese patients before and after bariatric surgery. ABCD Arq Bras Cir Dig. 2012;25(1):29-32

7. Tsuritani I, Honda R, Noborisaka $Y$, Ishida M, Ishizaki M, Yamada $Y$. Impact of obesity on musculoskeletal pain and difficulty of daily movements in Japanese middle-aged women. Maturitas. 2002;42(1):23-30.

8. Melissas J, Volakakis E, Hadjipavlou A. Low-Back Pain in morbidly obese patients and the effect of weight loss following surgery. Obes Surg. 2003;13(3):389-93.

9. Khoueir P, Black MH, Crookes PF, Kaufman HS, Katkhouda N, Wang MY. Prospective assessment of axial back pain symptoms before and after bariatric weight reduction surgery. Spine J. 2009;9(6):454-63.

10. Grans R, Warth CF, Farah JFM, Bassitt DP. Quality of life and prevalence of osteoarticular pain in patients submitted to bariatric surgery. Einstein (São Paulo). 2012:10(4):415-21.

11. Melissas J, Kontakis G, Volakakis E, Tsepetis T, Alegakis A, Alexander H. The Effect of Surgical Weight Reduction on Functional Status in Morbidly Obese Patients with Low Back Pain. Obes Surg. 2005;15(3):378-81.

12. Um panorama da saúde no Brasil: acesso e utilização dos serviços, condiç̃os de saúde e fatores de risco e proteção à saúde, 2008. Instituto Brasileiro de Geografia e Estatística. Pesquisa Nacional por Amostra de Domicílios. Rio de Janeiro: Instituto Brasileiro de Geografia e Estatística; 2010 (Acesso em 15 jan. 2019). Disponível em: https://biblioteca.ibge.gov.br/ biblioteca-catalogo?id=244356\&view=detalhes

13. Melissas J, Christodoulakis M, Schoretsanitis G, Sanidas E, Ganotakis E, Michaloudis D, et al.
Obesity-associated disorders before and after weight reduction by vertical banded gastroplasty in morbidly vs super obese individuals. Obes Surg. 2001;11:475- 81

14. Soccol FB, Peruzzo SS, Mortari D, Scortegagna G, Sbruzzi G, Santos C, et al. Prevalence of arthralgia in obese individuals in the pre and postoperative of bariatric surgery. Sci Med. 2009;19(2):69-74

15. Sociedade Brasileira de Cirurgia Bariátrica e Metabólica. [Acesso em 15 jan. 2019] Disponível em: https://www.sbcbm.org.br/

16. Moraes JM, Caregnato RCA, Schneider DS. Quality of life before and after bariatric surgery. Acta Paul Enferm. 2014;27(2):157-64.

17. Soccol FB, Peruzzo SS, Mortari D, Scortegagna G, Sbruzzi G, Santos PC, et al. Prevalence of arthralgia in obese individual in the pre and postoperative of bariatric surgery. Sci Med. 2009;19(2):69-74.

18. Polli GR, Falqueto H, Czarnobai I, Guerra PH, Giulliano D. Physical activity and low back pain in Brazilians: a systematic review. Rev Bras Ativ Fís Saúde. 2018;23:e0047.

19. Steffens D, Maher CG, Pereira LSM, Stevens ML, Oliveira VC, Chapple M, et al. Prevention of low back pain: a systematic review and meta-analysis. JAMA Intern Med. 2016;176(2):199-208.

20. Choi BKL, Verbeek JH, Tam WWS, Jiang JY. Exercises for prevention of recurrences of lowback pain. Cochrane Database Syst Rev. 2010;(1):CD012004.

21. Schopf PP, Allendorf DB, Schwanke CHA, Gottlieb MGV. Idade, sexo, raça/etnia são fatores intrínsecos associados à perda de massa muscular: uma revisão sistemática. Rev Bras Ci Mov. 2017;25(2):195-204.

22. Resende TIM, Meneguci J, Sasaki JE, Santos AS, Damião R. Sedentary behavior and reduced muscle mass in older adults: a population-based study. O Mundo da Saúde São Paulo. 2017;41(4):588-96.

23. Alves SP, Anjos RS, Feliciano FT, Lamarca F, Dutra ES, Carvalho KMB, et al. Association between muscular muscle force and functionality in patients submitted to bariatric surgery. RPBeCS. 2018;5(9):21-6.

24. Rodrigues LDS, Marota KB. 0 aumento da estabilidade lombar através da pré-ativação do músculo transverso do abdome. Revista Científica Univiçosa. 2015;7(1):249-53.

25. Boppre GF. Alterações da massa magra e massa óssea após cirurgia bariátrica. Efeitos de um programa de exercício físico [dissertação]. Porto, Portugal: Universidade do Porto; 2017 
Appendix 1. State of health questionnaire.

\section{OSWESTRY DISABILITY INDEX 2.0}

Could you please complete this questionnaire? It has been prepared to give us information about how your problem affects your day-to-day. Check only one box in each section, that which best describes you today.

\section{Section 1 - Pain intensity}

$\square$ I have no pain at the moment

$\square$ The pain is very mild at the moment

$\square$ The pain is moderate at the moment The pain is fairly severe at the moment The pain is very severe at the moment

$\square$ The pain is the worst imaginable at the moment

\section{Section 2 - Personal care (washing, dressing etc.)}

$\square$ I can look after myself normally without causing extra pain

$\square$ I can look after myself normally, but it causes extra pain

$\square$ It is painful to look after myself and I am slow and careful

$\square$ I need some help but manage most of my personal care

$\square$ I need help every day in most aspects of self-care

$\square$ I do not get dressed, I wash with difficulty and stay in bed

\section{Section 3 - Lifting}

$\square$ I can lift heavy weights without extra pain

$\square$ I can lift heavy weights, but it gives extra pain

$\square$ Pain prevents me from lifting heavy weights off the floor, but I can manage if they are conveniently placed e.g. on a table

$\square$ Pain prevents me from lifting heavy weights, but I can manage light to medium weights if they are conveniently positioned

$\square$ I can lift very light weights

I cannot lift or carry anything at all

\section{Section 4 - Walking*}

$\square$ Pain does not prevent me walking any distance

$\square$ Pain prevents me from walking more than 1 mile

$\square$ Pain prevents me from walking more than $1 / 2$ mile

$\square$ Pain prevents me from walking more than 100 yards

$\square$ I can only walk using a stick or crutches

$\square$ I am in bed most of the time

\section{Section 6 - Standing}

$\square$ I can stand as long as I want without extra pain

$\square$ I can stand as long as I want but it gives me extra pain

$\square$ Pain prevents me from standing for more than 1 hour

$\square$ Pain prevents me from standing for more than 30 minutes

$\square$ Pain prevents me from standing for more than 10 minutes

$\square$ Pain prevents me from standing at all

\section{Section 7 - Sleeping}

$\square$ My sleep is never disturbed by pain

$\square$ My sleep is occasionally disturbed by pain

$\square$ Because of pain I have less than 6 hours sleep

$\square$ Because of pain I have less than 4 hours sleep

$\square$ Because of pain I have less than 2 hours sleep

$\square$ Pain prevents me from sleeping at all

\section{Section 8 - Sex life (if applicable)}

$\square$ My sex life is normal and causes no extra pain

$\square$ My sex life is normal but causes some extra pain

$\square$ My sex life is nearly normal but is very painful

$\square$ My sex life is severely restricted by pain

$\square$ My sex life is nearly absent because of pain

$\square$ Pain prevents any sex life at all

\section{Section 9 - Social life}

$\square$ My social life is normal and gives me no extra pain

$\square$ My social life is normal but increases the degree of pain

$\square$ Pain has no significant effect on my social life apart from limiting my more energetic interests e.g., sports

$\square$ Pain has restricted my social life and I do not go out as often

$\square$ Pain has restricted my social life to my home

$\square$ I have no social life because of pain

\section{Section 10 - Travelling}

\section{Section 5 - Sitting}

$\square$ I can sit in any chair as long as I like

$\square$ I can only sit in my favorite chair as long as I like

$\square$ Pain prevents me sitting more than one hour

$\square$ Pain prevents me from sitting more than 30 minutes

$\square$ Pain prevents me from sitting more than 10 minutes

$\square$ Pain prevents me from sitting at all $\square$ I can travel anywhere without pain

$\square$ I can travel anywhere but it gives me extra pain

$\square$ Pain is bad but I manage journeys over two hours

$\square$ Pain restricts me to journeys of less than one hour

$\square$ Pain restricts me to short necessary journeys under 30 minutes

$\square$ Pain prevents me from travelling except to receive treatment 
Appendix 2. Oswestry Disability Index

\section{QUALITY OF LIFE QUESTIONNAIRE (SF36V2)}

Instructions: This survey asks for your views about your health, how you feel and how well you are able to do your usual activities.

We ask you to read each question carefully and answer as honestly as possible. If you are not sure about your answer, provide the answer you think is most appropriate and, if you wish, leave a comment after the question.

For question 1 and 2, please circle the number that best describes your health. For each of the questions 6,7 , and 8 , please circle the number that best

1. In general, would you say your health is:

\begin{tabular}{ccccc} 
Excellent & Very Good & Good & Fair & Poor \\
1 & 2 & 3 & 4 & 5 \\
\hline
\end{tabular}

2. Compared to one year ago, how would you rate your health in general now: Much better Somewhat About the same Somewhat Much worse

\begin{tabular}{ccccc|}
\multicolumn{4}{c}{ better } & worse \\
1 & 2 & 3 & 4 & 5 \\
\hline
\end{tabular}

3. The following questions are about activities you might do during a typical day. Does your health now limit you in these activities? If so, how much?

(Please circle one number on each line) Yes, Yes, No, not limited limited limited a lot a little at all

a. Vigorous activities, such as running, lifting heavy

objects, participating in strenuous activities.

$\begin{array}{lll}1 & 2 & 3\end{array}$

b. Moderate activities, such as moving a table

pushing a vacuum cleaner.

c. Lifting or carrying groceries

d. Climbing several flights of stairs

e. Climbing one flight of stairs.

f. Bending, kneeling, or stooping

g. Walking more than a mile......

h. Walking several hundred yards.

i. Walking one hundred yards.

j. Bathing or dressing yourself.

Copyright (๑) 1992. New England Medical Center Hospital, Inc. All rights reserved.

4. During the past 4 weeks, how much of the time have you had any of the following problems with your work or other regular daily activities as a result of your physical health?

How much of the time during the All of Most Some A little None past 4 weeks.

a. Cut down on the amount of

time you spent on work or other

the of the of the of the of the

time time time time time

activities

b. Accomplished less

than you would have

liked?

c. Were limited in the kind of work or

other activities

d. Had difficulty performing the work

or other activities (for example, it took

extra effort)

$\begin{array}{lllll}1 & 2 & 3 & 4 & 5\end{array}$

5. During the past 4 weeks, how much of the time have you had any of the following problems with your work or other regular daily activities as a result of any emotional problems (such as feeling depressed or anxious)?

How much of the time during the All of Most Some A little None past 4 weeks... the of the of the of the of the \begin{tabular}{|lccccc} 
& time & time & time & time & time \\
\hline a. Cut down the amount of & 1 & 2 & 3 & 4 & 5
\end{tabular} time you spent on work or other

activities.

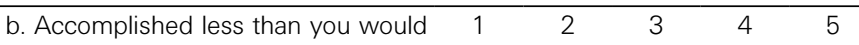
like?.

c. Did your work or activities less carefully than

usual. describes your health.

6. During the past 4 weeks, to what extent has your physical health or emotional problems interfered with your normal social activities with family, friends, neighbors, or groups?

$\begin{array}{ccccc}\text { Not at all } & \text { Slightly } & \text { Moderately } & \text { Quite a bit } & \text { Extremely } \\ 1 & 2 & 3 & 4 & 5\end{array}$

\begin{tabular}{|cccccc|}
\hline 7. How much bodily pain have you had during the past 4 weeks? \\
None & Very mild & Mild & Moderate & Severe & Very severe \\
1 & 2 & 3 & 4 & 5 & 6 \\
\hline
\end{tabular}

8. During the past 4 weeks, how much did pain interfere with your normal work (including both work outside the home and housework)?

$\begin{array}{ccccc}\text { Not at all } & \text { Slightly } & \text { Moderately } & \text { Quite a bit } & \text { Extremely } \\ 1 & 2 & 3 & 4 & 5\end{array}$

9. These questions are about how you feel and how things have been with you during the past 4 weeks.

For each question, please give the one answer that comes closest to the way you have been feeling.

Make sure that you circle one number on each line.

How much of the time during the past 4 All of Most Some A little None

weeks... the of the of the of the of the

\begin{tabular}{c} 
time time time time time \\
\hline a.
\end{tabular}

\begin{tabular}{|llllll|}
\hline a. Did you feel full of life? .............. & 1 & 2 & 3 & 4 & 5 \\
\hline b. Have you been very & 1 & 2 & 3 & 4 & 5
\end{tabular}

nervous?

c. Have you felt so down in the

dumps that nothing could cheer you

up?...

\begin{tabular}{|c|c|c|c|c|c|}
\hline d. Have you felt calm and peaceful?.. & 1 & 2 & 3 & 4 & 5 \\
\hline e. Did you have a lot of energy?.................... & 1 & 2 & 3 & 4 & 5 \\
\hline $\begin{array}{l}\text { f. Have you felt downhearted and } \\
\text { depressed? }\end{array}$ & 1 & 2 & 3 & 4 & \\
\hline g. Did you feel worn out?.................................. & 1 & 2 & 3 & 4 & \\
\hline h. Have you been happy?..... & 1 & 2 & 3 & 4 & \\
\hline i. Did you feel tired? & 1 & 2 & 3 & 4 & \\
\hline
\end{tabular}

10. During the past 4 weeks, how much of the time has your physical health or emotional problems interfered with your social activities (like visiting with friends, relatives, etc.)?

$\begin{array}{ccccc}\text { All of the time } & \begin{array}{c}\text { Most of the } \\ \text { time }\end{array} & \begin{array}{c}\text { Some of the } \\ \text { time }\end{array} & \begin{array}{c}\text { A little of the } \\ \text { time }\end{array} & \begin{array}{c}\text { None of the } \\ \text { time }\end{array} \\ 1 & 2 & 3 & 4 & 5\end{array}$

11. How TRUE or FALSE is each of the following statements for you. Circle one number on each line.

Definitely True

Mostly Don't Mostly Definitely True Know False False

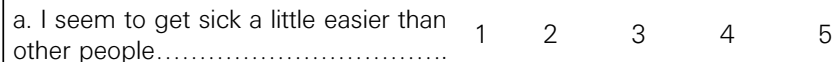

b. I am as healthy as anybody I

know.

c. I expect my health to get

worse

d. My health is excellent.

$\begin{array}{lllll}1 & 2 & 3 & 4 & 5 \\ 1 & 2 & 3 & 4 & 5 \\ 1 & 2 & 3 & 4 & 5\end{array}$

